\title{
Distortion of Nepalese Culture and Social Norms in Upadhyay's Buddha's Orphans
}

\section{Ramesh Prasad Adhikary}

Assistant Professor, Tribhuwan University, Kathmandu, M.M. Campus, Nepalgunj, NEPAL

Corresponding Contact:

Email: rameshadhikary29@gmail.com

Manuscript Received: 25 June 2020 - Revised: 08 August 2020 - Accepted: 15 August 2020

\begin{abstract}
This research article is mainly focused on how Samrat Upadhyay has distorted Nepalese Culture and social norms in is novel Buddha's Orphans. Nepalese culture and society are represented in a biased way from the western perspective. By using oriental stereotypes, the author has represented Nepal and the religious belief of Nepalese people in a wrong way. The characters of this novel like Bokey Ba, Kaki, Raja, Jamuna and Ganga Da are presented as irrational and badly conservative people who believe in witch doctors, not in the medical doctors. They are presented as impulsive and eccentric. The setting of this novel is represented as exotic, inscrutable and mysterious. Kathmandu valley and Nepalese people didn't well describe as the real Kathmandu. As a qualitative research, the researcher has taken the novel as primary text and the concepts from orientalism, and Foucauldian notion of representation are used as a tool to interpret the text. The researcher concluded that the novel is misrepresentation of Nepalese culture and society.
\end{abstract}

Keywords: orientalism, stereotype, culture, social norms

This article is is licensed under a Creative Commons Attribution-NonCommercial 4.0 International License.

Attribution-NonCommercial (CC BY-NC) license lets others remix, tweak, and build upon work non-commercially, and although the new works must also acknowledge \& be non-commercial.

\section{INTRODUCTION}

Samrat Upadhyay is the leading diasporic writer who writes mostly about Nepal. Upadhyay was born in Nepal; later on he emigrated to United States of America in his childhood. From the western point of view, he has been writing on Nepalese culture and society. Upadhyay views Nepalese subjects from the western point of view, which is called as Orientalist vision. The main subject matters of his novels range from history, royal massacre culture etc. Guru of Love, Arresting God in Kathmandu, and Royal Ghost are some of the popular works of Sarmrat Upadhyay. All of these works have represented Nepalese society and culture in a faulty way.

Samrat Upadhyay's novel, Buddha's Orphan, has wrong assumption or point of view to represents Nepal and Nepalese culture. The culture and religious faith of Nepalese people are falsely portrayed in this novel. He seems unknown about the changes in Nepalese 
culture and people. He has presented Nepalese culture and mindset of Nepalese people in a biased way. He represents Nepalese people and Nepal in such a way that it could fulfill the interest of the western readers. Taking the Buddhist's notion that human beings are all connected to one another due to suffering, Upadhaya represents how Nepalese citizens are locked in it. Kathmandu City is which is used as the setting of the novel. The lives of people living in Kathmandu are presented in the novel. Nepalese people's struggle for freedom from tyranny, helplessness of orphans, lack of love and care in old age, etc. are presented in a biased way.

The novel focuses on the birth, nurturing and upbringing of an orphan boy named Raja. Nepalese society is shown as a typical society in which people's struggle for freedom from their miserable condition. Nepalese society tries to come out of the cocoon of comfortable convention. But circumstances hardly stand in its favor. A woman, named Mohini, who is the mother of Raja, the orphan, drowns in Rani Pokhari. Her son becomes orphan. When the orphan infant is taken to the child care world run by the government, the responsible person scolds very bitterly to Kaki and Bokey Ba. The official person says that their child care center does not accommodate the orphan. The irresponsibility on the part of the holders of government offices is the distinguishing feature of Nepalese society. Ganga Da, who works in the Planning Commission, has fallen into the net of corruption. He constructs a large building with the money he takes illegally from the Commission

\section{Hypothesis of the study}

The researcher has hypothesized that there are problems and prejudices in Upadhyay's representation of Nepalese society. Though plenty of reforms and developments have occurred in cultural, social and political conditions of Nepalese people, Upadhyay presents Nepalese culture as it is based on superstitions. His diasporic existence made him to interpret Nepalese culture in a biased way to entertain the metropolitan readers.

\section{Objective of the Study}

The major objective of this research is to expose how Upadhaya has presented Nepalese culture and society in a biased way. By using orientalists' notion, he has misrepresented Nepale culture in the novel. To entertain the metropolitan readers, he has misrepresented Nepalese culture in it. The deep-rooted caste contamination, gender inequality, Nepalese people in poverty and helpless condition, expression of lust and greed, lazy bureaucracy and corrupt administration are all depicted to entertain the western readers.

\section{Limitation of the study}

This research is solely focused on Buddha's Orphans. The researcher has used the theory of representation and orientalist notion of westerners' vision as a tool to interpret the novel to gain the objective how the diasporic writer intentionally represented Nepalese society and culture in a biased way.

\section{REVIEW OF RELATED LITERATURE}

From the day of its release, Buddha's Orphans had attracted the attention of many critics and it has been interpreted from various perspectives. Thapa a Nepali critic has analyzed Upadhyay's Buddha's Orphans as it captures Nepalese history from the end of Rana regime to the moment prior to the event of Royal massacre. Thapa (2011) comments as: 
Samrat Upadhyay's fiction has tended to be small in scale, charting the infinitesimal tremors of middle-class angst. Who was born and raised in Nepal, now makes his home - is at times almost incidental. [...] You need to get a job so we can start thinking about a child. The fretting, the obsessive nostalgia, the muffled ache: it's all distressingly familiar. We have scaled the roof of the world and met ourselves. (21)

It means that the middle class angst and stress are brought to the center of the novel. Suffering is the universal feature which Samrat has kept in philosophical context. The Buddhist philosophy of human sufferings is dramatized in the broader context of the narrative.

Another critic Mishan (2011) assumes that the harsh reality is handled in this novel in a fantastic way. There is a difference between the practical reality and the reality introduced in a work of art. Mishan (2011) gives the following remarks:

The story traverses half a century of political and social upheaval in Nepal, from the 1960s to the present day. From the opening scene, in which a young mother abandons her baby and then commits suicide, the novel takes the aerial view, providing geographical coordinates and historical context. The year is 1962; the child is left on the parade ground, site of future anti-government demonstrations; the girl drowns herself in a pond built to console a queen mourning a lost son. (31)

Here, Buddha's Orphan differs drastically from other previous novels. A woman commits suicide in the pond that has historical importance. From common incidence to events having serious political importance are mentioned in the novel.

Journalist and critic Dixit (2012) states Buddha's Orphans reminds us that there was a Kathmandu before 1990. Upadhyay has gone to some effort to recreate the setting in which his characters take root. Dixit (2012) makes the following disclosure with respect to the novel, Buddha's Orphans:

Whatever charm there is in Upadhyay's straightforward, detailed prose is diminished by the sloppy editing, which is an affront to Nepali audiences. If there is a true orphan in this tale, it has to be the novel itself. Thus we are introduced, obliquely, to Raja, as the foundling is named by his indigent rescuers. In literature, there's something liberating about being an orphan. (47)

The novelist must have been familiar with the surrounding of Kathmandu, The author has certain degree of familiarity with the culture, social system and political agitation of Nepal. But he depicts all these things as though they are surreal and exotic

Dyer (2010) the noted reviewer and critic, finds out the subversive elements in the novel Buddha's Orphans. In the Nepalese society where no woman dares to express her desire for another man openly, Nilu freely begins to live with a man other than her husband. Along with such a immoral act, the fallout of the underground Maoist insurgency is also mentioned in the novel.

The critics and reviewers examined the novel from different perspectives and arrived at various findings, none of them investigated the presence of author's misrepresentation and biasness on representation of Nepalese culture. The orientalist bias in the representation of Nepalese culture, to entertain the metropolitan readers is untouched by those critics. So the researcher has interpreted it in a new light. 


\section{THEORETICAL FRAMEWORK}

To conduct the research, the researcher has used orientalism as a tool. Edward Said's assumes orientalism contains the biased attitude of the westerners towards the language, culture, civilization and manners of people of East. The concept is used to make the methodological framework of the research. The representation is always affected by the interest of the group who holds influence in the process of the production of discourse. Foucault (1998) is of the opinion that there is always the effect of power in the production of discourse regarding any event, phenomenon or culture. Nobody or no institution produces discourses out of the free will. Certain degree of politics is bound to enter the surface of textual representation.

Said (1998) presents the difference between east and west, as orientalists put in discourse of orientalism. He says that with the start of European colonization the Europeans came in contact with the lesser developed countries of the east. They found their civilization and culture very exotic, and established the science of orientalism. Orientalism is the study of the eastern people or the people from these exotic civilization. Edward Said argues that the Europeans divided the world into two parts; the east and the west or the occident and the orient or the civilized and the uncivilized. This was totally an artificial boundary. And it was laid on the basis of the concept of them and us or theirs and ours.

Some additional ideas of Said become pertinent here. Said (1998) argues that Europeans defined themselves while defining oriental people and oriental culture. The definition of oriental culture and people helps the European people to project their self and identity. Orientalists use a stock of stereotypical remarks to depict the oriental culture and oriental civilization:

The most important use of orientalism to the Europeans was that they defined themselves by defining the Orientals. For example, qualities such as lazy, irrational, uncivilized, crudeness were related to the Orientals, and automatically the Europeans became active, rational, civilized, sophisticated. Thus, in order to achieve this goal, it was very necessary for the orientalists to generalize the culture of the orients. Another feature of orientalism was that the culture of the Orientals was explained to the European audience by linking them to the western culture, for example, Islam was made into Mohammadism because Mohammad was the founder of this religion and since religion of Christ was called Christianity; thus Islam should be called Mohammadism. (143)

Here, the remarks contain plenty of orientalist stereotypes. These stereotypes are suggestive of how well-organized and systematic is the politics behind the productions of orientalist texts. Michel Foucault (1998) argue that the new notion of truth is formed out of discursive practice. He categorically rejects the effects of ideology in the productions of knowledge. Discursive framework is largely responsible for the origin of a new mode in which discourse about culture and history circulates. The production of discourse about culture and history is affected by power groups. At the same time, the circulating truths and knowledge generate a sort of power. As Foucault (1998) argues:

With the emergence of post-structuralism, a shift from ideology to discourse in social theory took an upper hand. Let us begin with the two main tendencies in poststructuralism: textuality and discursivity. Textuality refers to a movement within literary, cultural theory and in philosophy emphasizing the revaluation and revalorization of text as text. Textual researches focus on language as a producer of 
meaning rather than a pale reflection of some prior reality. Discursivity on the other hand, has an area of research much broader than textual analyses. (70)

Foucault's discourse describes how traditions, norms, rules, texts, symbols, words and expressions are created by power. These contents demonstrate hierarchical power relations. Discursive research focuses on the question of how rather than why. They do not look for causal explanations. Foucault analyzes different institutions and other discursive unities to detect power relations. According to Foucault, statements and truth-claim spread and take the form of hegemony. With the hegemony, truth-claim gradually transform into the regime of truth.

According to Foucault (1997), the idea of taking out pure truth from a discourse is sure to fail. In the following lines Foucault stand on the absolute representative power of representation?

Foucault maintains that the great turn in modern philosophy occurs when, with Kant, it becomes possible to raise the question of whether ideas do in fact represent their objects and, if so, how they do so. In other words, ideas are no longer taken as the unproblematic vehicles of knowledge; it is now possible to think that knowledge might be something other than representation. This did not mean that representation had nothing at all to do with knowledge. Perhaps some knowledge still essentially involved ideas' representing objects. But, Foucault insists, the thought that was only now possible was that representation itself could have an origin in something else. (171)

Here, he means to say every mode of representation is problematical. But this problematical nature of representation is actually the true characteristic of representation. Judged from the classical point of view, the postmodern narration or representation is problematical. But viewed from the workable perspective, it is the exact characteristic of representation. This thought, according to Foucault, led to some important and distinctively modern possibilities. Not, however, produced by the mind as a natural or historical reality, but as belonging to a special realm of knowledge.

\section{ANALYSIS OF the NOVEL}

The novel Buddha's Orphans represents Nepalese society and culture in a biased way. Kathmandu valley is portrayed as the exotic city that is torn between the temptation of modernity and the burden of tradition. Upadhyay presents Nepalese families as if they are loose and fragile. No coherent cultural forces bind Nepalese society. The family of Ganga $\mathrm{Da}$ is on the verge of disintegration. His wife, Jamuna is insane and schizophrenic. Kaki's son kicks her from his house. Even the educated ladies like, Nilu and Prateema believes in superstitious practice. Muwa is a drunkard and gambler women who enjoys living together with half a age younger boy being irresponsible toward her daughter Nilu.

In this novel, Upadhyay presents the story of a mother, who happens to be a mother without any sense of being able to give birth to her baby and then nurture and take care of her baby. An unknown mother gives birth to a baby. Perhaps due to the fear of being shamed and embarrassed, she dies getting drowned in Rani Pokhari. This pond has religious and historical significance. But the author does not care for its historical and spiritual significance. He simply plays with its importance hilariously. He is not aware of its importance. He upholds condescending attitude to it. That is why he portrays this pond as a site in which an illegitimate woman, who gives birth to a baby, dies by getting 
drowned in it. To show an illegitimate woman die by drowning on it is to contaminate and poison this pond. Such representation reflects author's metropolitan biases and orientalist prejudices. The following lines cited from the novel illustrate and expose how condescending is author's attitude towards Nepalese

The Main point of this research is that Upadhyay's treatment of Nepalese culture and religion is problematic. Nepalese culture and the Nepalese people's religious faith are falsely presented in Buddha's Orphans. These are the evidences in the texts which clarify author's orientalist biases. He portrays Nepalese people as impulsive and exotic. The unusual elements and temperament exist highly in their behaviors and activities. Kaki is one of the character of this novel and Upadhyay portrays her highly unpredictable and impulsive. Out of her maternal affection she does wrong judgement by nurturing an orphan infant, because she is too poor to nurture him. Similarly, Bokey Ba commits the same mistake. He puts the unknown and unidentified baby on Kaki's lap and abandons. Ganga Da is too irrational to marry a woman who is schizophrenic. His simple belief in arrange marriage brings him to the path of tragic life. Throughout his life he has to live with a mad woman disregarding the happiness of conjugal life.

Upahdayay is orientalist in this text, because he is criticizing to humiliate the oriental people and culture by using different characters in the novel. Upadhyay projects his oriental biasness toward Nepal and Nepalese culture being orient himself. Though on the surface level of the novel he presents political upheaval of Nepal from 1960's to the present situation along with the story of young lovers, but in deeper level, we find his orientalist attitude. He depicts Nepali people as stoic, visionless, poor, superstitious, religious, insane, impulsive and uneducated which is opposite to occident or westerners. Through various issues, characters' portrayal, their behavior and setting, we can find his hidden biased notion.

The characters like Kaki and Bokey Ba are represented as very poor Nepalese in the condition of homelessness. Bokey Ba dies due to the cold, lack of shelter, care and medicine. Kaki also makes her livelihood by selling corn in Ratna Park, who is abandoned by her own son and daughter-in-law and she is left homeless. One morning, Kaki's son kicks her out of the house. His harsh treatment is unexpected. He complains her of stealing money from his mattress. The rest of the day Kaki roams the city with her belongings. She is in too weak condition to carry her belongings and she roams in search of shelter.

The beliefs and customs of Nepalese people are presented with full of prejudices feeling of the writer. Ganga Da is a government employee who works in planning commission; but he is a corrupt bureaucrat and faithful follower of monarchy. He has constructed a house by using money which he misused from government fund. Although he is prosperous and rich, he is not happy but is in really pathetic condition. His wife is schizophrenic. Her activities and reaction puts Ganga Da in distress. His mad wife reacts in an unexpected way. She has become burden to him. She is a sterile woman. Ganga Da is carrying a burden of his wife's schizophrenia and sterility. In this novel, Upadhyay portrays some Nepalese families stereotypically in the way the orientalist scholars represent and dominate the orient in their work. All the families he portrays in this novel face problems regarding social norms and values. In some family, daughters elope, in some mother is drunkard and irresponsible toward own children, in some son kicks his old mother, in some, women are mad and burden to her own family, in some, girl dies of illegal relationship in young age. So, Upadhyay hardly deals withthe speciality of Nepalese 
family positively and sensitively. To him, Nepalese families are weak and fragile. Such biased representation of Nepalese society by author is unacceptable.

The setting of this novel is presented with negative words as shapeless and crime prone like what Orientalist says about the major cities of the orient. Upadhyay says that Kathmandu valley as crime prone city. To him, this city has the feature of unrest, instability and full of metropolitan trick. Ganga Da is also a resident of the same city and he is so cunning and fraud that he snatches other peoples' children and makes his own by making duplicate document of birth certificate. He snatches Raja away from Kaki, who has nurtured Raja when he was infant. He bribes the staff of Patan Hospital to make forge birth certificate of Raja to cure his schizophrenic wife. So, in this city, this sort of people are dwelling who can cheat and trick other people very easily.

As the people were fighting against monarchy, they was always strike and normal life was always disturbed, poor people's livelywood is very badly disturbed. Due to strike in Kathmandu valley Nilu's Maitreya dies untimely because of lack of treatment on time. In the same city, youths with progressive and democratic consciousness are demanding reform and multiparty democracy. But in the same city, some blind followers of king are crying that they need their king - god because they worship king as the incarnation of Lord Bishnu. Upadhyay presents the city of Kathmandu torn between ideological superstition and political modernism.

His biases nature is also seen in the representation of female characters in this novel. Upadhyay has presented female characters keeping orientalist biases in his mind. Female characters are represented as the blind believers of superstition and fake cultural practice. Kaki is helpless character in her own house, Ganga Da's wife, Jamuna is schizophrenic. Ganga Da's mother is too much spiritual and leaves all the material things and leads the life of Saint. And most of the female characters are represented as lecherous creatures only. To exemplify this, we can take the name of Muwa. She is a 'widow' who lost her husband in an accident in her youthful age. She is very prosperous in terms of material property, she is living with her daughter Nilu and starts having relationship with a boy Sumit who is half a age younger than her. She is enjoying living together with Sumit, she is drunkard and gambler at the same time. The important thing is that living together is not practiced in Nepalese society. But Upadhyay shows Nepalese women living together with their respective male partner. Nilu also elopes with Raja without the consent of family. And her daughter Ranjana also returns from America with a child of Habsi on her womb. Not only this, Mohini, who is Raja's dead mother has such story. She bears child before her marriage which is against Nepalese social norms and values and she is compelled to commit suicide in Ranipokhari. Such representation of female character by Upadhyay clarifies that either Nepalese women are harmfully spiritual or embarrassingly lecherous.

Although there might be some lesbians in Nepalese society, we can hardly find open lesbian practice. But the author exhibits the lesbian attraction between Sister Agnes and Nilu in the text. Upadhyay wants to show that lesbian practice is wild in Nepalese society. This is condescending attitude of author toward Nepal and Nepalese people. And another important thing is that he has depicted Buddhist monasticism with orientalist attitude and full of orientalist prejudice. He has portrayed Buddhist monastery Swayambhunath as love making place of young lovers. Not only this, he has blamed the young monks for their voyeuristic graze upon Nilu and young lovers who visit Swayambhunath. This is 
very wrong notion and biased attitude of author. This is the biased view of Upadhyay toward Nepalese culture, society and religion.

\section{CONCLUSION}

From the above analysis, the researcher comes to the conclusion that the biased view of the Upadhayay is reflected in this novel Buddha's Orphans. His representation has nothing to do with the concrete and pure reality. Upadhyay's metropolitan stand is reflected in this novel. His attitude toward Nepalese and their culture is unacceptable. So, to make happy the western metropolitan audience, he represents Nepalese people with biased Orientalistic attitude in this novel. He might have desire to gain economic benefit from the western world by representing Nepalese people in such biased way. So, there is politics of representation in this work of Upadhyay.

\section{REFERENCES}

Adhikary, R. P. (2020). Dismantling the Patriarchal Hierarchy in Willa Cather's A Lost Lady. ABC Journal of Advanced Research, 9(1), 19-30. https://doi.org/10.18034/abcjar.v9i1.498

Dixit, K. (2012). Unheard Voice. Kathmandu: Nepalaya.

Dyer, W. (2010) Diasporic Pathos. New York: Norton.

Foucault, M. (1997). The Order of Things. London: Harper Collins.

Foucault, M. (1998) The Theory of Power. London: Macmillan.

Mishan, L. (2011). Diasporic Voice in Alien Land. New Delhi: Pilgrim Publication.

Said, E. (1998). Orientalism. New York: Penguin.

Said, E.W. (1994). Culture and Imperialism. New York: Penguin.

Thapa, R. (2011). Nepalese Literature: A Critical Reflection. New Delhi: Diamond Publication.

Upadhyay, S. (2010). Buddha's Orphans. New Delhi: Rupa Publication.

\section{Biography of the author}

Dr. Ramesh Prasad Adhikary is an assistant professor of Tribhuwan Univeristy, Kathmandu, Nepal. He has been teaching English literature at M.M. Campus since 2007. He has completed his PhD in Existential philosophy and has been doing his research on English language, literature and literary theories. He has created more than 40 international articles and 18 books on various topics of English literature.

$$
--0-
$$

\section{How to cite this article}

Adhikary, R. P. (2020). Distortion of Nepalese Culture and Social Norms in Upadhyay's Buddha's Orphans. ABC Journal of Advanced Research,9(2), 45-52. https://doi.org/10.18034/abcjar.v9i2.504 